\title{
PML wt Allele
}

National Cancer Institute

\section{Source}

National Cancer Institute. PML wt Allele. NCI Thesaurus. Code C53102.

Human PML wild-type allele is located in the vicinity of $15 q 22$ and is approximately $53 \mathrm{~kb}$ in length. This allele, which encodes probable transcription factor PML protein, plays a role in transcription, repair, recombination of DNA and apoptosis through the formation of specialized bodies (PML bodies) of nuclear proteins. Acute promyelocytic leukemia is associated with the translocation $\mathrm{t}(15 ; 17)(\mathrm{q} 22 ; \mathrm{q} 21)$ of the gene and the RARA gene. 